\title{
Are neighbours alike? Practices of conviviality in Catalonia and Casamance
}

\author{
Tilmann Heil \\ University of Konstanz, Germany
}

\begin{abstract}
Living together in neighbourhoods characterised by various aspects of diversity is central to the everyday life of Casamançais in both Catalonia, Spain, and Casamance, Senegal. Discursively, Casamançais speak about it similarly in both localities, construing co-residence on the neighbourhood scale as a sociality that builds on similar moral values such as relative equality, respect and consideration. At the same time, this sociality also implies negotiation, interaction and translation as central everyday practices. Investigating these practices reveals how they facilitate locally specific forms of neighbourliness. These practices are central to the suggested conceptualisation of conviviality as a process in which a fragile balance is maintained over the course of both cooperative and conflictual situations.
\end{abstract}

\section{Keywords}

Conflict, conviviality, everyday, migration, neighbourliness, residency, Senegal, Spain, translation

\section{Introduction}

In Casamance, a region in the south of Senegal, a saying goes, 'Ton voisin est ton plus proche parent', ${ }^{1}$ which in an urban context introduces the following reasoning: Since your blood relatives might be far away in your home village or distant towns in the subregion, it is a neighbour, someone living in relative physical proximity, who will help you in case of need. The examples of actual assistance substantiating this claim are manifold and vary in terms of the degree of commitment involved. In Ziguinchor, the capital

Corresponding author:

Tilmann Heil, Center of Excellence 'Cultural Foundations of Integration', University of Konstanz, P.O. Box 213, Universitätsstrasse 10, 78457 Konstanz, Germany.

Email: tilmann.heil@uni-konstanz.de 
of Lower Casamance, one of my interlocutors, Papis Sonko, ${ }^{2}$ gave many examples of actions of neighbourliness, such as dousing a fire, providing food, looking after the children or helping prepare celebrations. Yet, some people, including migrants visiting Casamance, distrusted their neighbours to the extent that they did not eat or drink there out of a fear of being poisoned. This fear stemmed from envy that many Casamançais perceived to exist between certain neighbours and their migrant family members, a perception that was usually already in place prior to migration but that tended to increase dependent on perceived migration success. In this article, I use selected examples of discourses of neighbourliness and manifestations of it to enquire into conviviality, the fragile process of locally living with difference. The ethnography of neighbourliness in Casamance, Senegal, and Catalonia, Spain, will contribute to the conceptual understanding of conviviality as this fragile process that encompasses both cooperative and conflictual encounters on the basis of relative equality, mutual respect and consideration.

In contrast to Casamance, Casamançais in Catalonia expected neighbourliness to be different due to people's likely maintenance of stronger individual concerns. This was confirmed when they experienced the absence even of greeting among neighbours. However, Sounkar Deme had a neighbour who helped out whenever he needed her support. Thus, Casamançais' experiences of relationships with neighbours sometimes confirmed and at other times contradicted their expectations of neighbourliness in Catalonia. This also depends on how far the normative underpinnings of neighbourliness migrate with Casamançais as part of their values, or whether their moral compass is overridden and 'Europeanised'. I thus ask what the local contextual influences on neighbourliness are versus those from within the transnational social field (Levitt and Glick Schiller, 2004: 1009). I question the extent to which neighbourliness draws from transnationally circulating values and how local social institutions change them.

Although Casamançais frequently expected neighbourliness to be diametrically opposed in Catalonia and Casamance and represented them stereotypically for both sites, the experiences of neighbourliness are indeed heterogeneous in both localities. I will therefore try to analytically distinguish social change over time within the same locality from changes in conceptions of neighbourliness due to migration.

Drawing from 18 months of fieldwork equally split between Catalonia and Casamance, in this article, I address how neighbourliness discourses inform the conceptualisation of the process of conviviality and to what extent its normative connotations impact on everyday encounters of conviviality. ${ }^{3}$ I will differentiate into discourses the representations of neighbourliness, and practices by which I refer to lived experiences in encounters. In general, neighbourliness concerned the people staying next door as well as those living in the area that my interlocutors easily reached by foot (cf. Heil, forthcoming). In this article, I present the perspective of mainly Casamançais men, both migrants in Catalonia and their family members and friends in Casamance. I did not have the same access to women migrants, which is why their perspective is mostly missing from this research. I compare the experiences of Casamançais in two neighbourhoods, of Casamançais migrants in Cerdanyola in Mataró (Catalonia), and of their families and friends in Lindiane in Ziguinchor (Casamance).

In the following, I will first give some empirical background on the transnational migration of Casamançais and their housing patterns in diverse neighbourhoods in 
Catalonia and Casamance to emphasise the relevance of conceptualising conviviality, living with difference. Second, I will analyse the place of neighbourliness in the political as well as local discourses of convivència and cohabitation in order to contrast this with practices of neighbourliness in a third part. I will engage with aspects of neighbourliness which suggest interaction, negotiation and translation as basic practices of conviviality. In view of the current academic discussions of conviviality as mundane and everydaylike, I will conclude that the analysis of neighbourliness has suggested these basic practices as an innovative way of conceptualising conviviality as a process of both cooperative and conflictual encounters in fragile and changing diverse local configurations.

\section{Living in mixed neighbourhoods}

My field sites were characterised by diverse configurations of people. Ethnically mixed neighbourhoods constitute large parts of both Catalan and Casamançais towns. As a result of three decades of immigration, Spain's population has diversified. Within Spain, the autonomous region of Catalonia is a primary destination for immigrants with a foreign-born population of 17.5 percent compared to the national average of 14 percent in 2010 (Instituto Nacional de Estadística, 2011). Casamançais migrants concentrate in certain parts of Catalonia, such as the Maresme county and Mataró, the county seat. ${ }^{4}$

Cerdanyola is a peripheral neighbourhood of Mataró and offers a typical example of the neighbourhoods, characterised by various aspects of diversity, of many of the middle-sized industrial towns of Catalonia. The neighbourhood was built during the heavy influx of internal Castilian labour migrants from the south of Spain in the 1950s and 1960s (cf. Bover and Velilla, 2005; Lligadas, 2000; Silvestre Rodríguez, 2002). During my fieldwork, the neighbourhood did not appear to be segregated. People of all stripes were coinciding in public. For example, in the Parc de Cerdanyola, women from all parts of the world were standing in groups in the area of the playground and chatting on a summer Sunday afternoon. There were sub-Saharan and North Africans, Asians and Europeans. A visibly very diverse crowd of boys played football in mixed teams. Elsewhere in the park, small gatherings of elderly Southern European men coincided with other inhabitants of the neighbourhood.

The coexistence of Castilian and Catalan speakers, dating back to the 1950s, today is complimented by the influx of international migrants of diverse origins, from 120 different nation states, and even more ethnic and language groups. Local statistics show that one in four inhabitants of Cerdanyola is born outside Spain, while every second resident is born outside of Catalonia (Ajuntament de Mataró, 2010). Of those born outside Spain, the majority is from Morocco (44.5\%), and more than one in five is from Senegal or The Gambia. Other large groups are Chinese and Latin Americans. At least every eighth person is Muslim in Cerdanyola. ${ }^{5}$ This is double the share of the Catalan average in 2008 (Moreras, 2008: 18). These are the configurations in which the everyday life encounters of neighbours and their discourses of conviviality take place.

In Casamance, my initial impression of urban space was different from Cerdanyola. Lindiane, a peripheral neighbourhood of Ziguinchor, the capital of the lower Casamance, has no freshly refurbished parks or other communal infrastructures; rather, the only wide boulevard was nearly fully eroded. Although there was some traffic, the boulevard was a 
space for casual encounters, as were the street corners and the footpaths spread around the neighbourhood. Neighbours passed and greeted each other, groups sat in front of corner shops and house entrances, elderly men gathered at the small mosque in the shade, and in the evening women sold vegetables and fish along the boulevard.

As in Catalonia, this was the scene of a migrant neighbourhood, since Casamance is strongly characterised by migration flows that have resulted in ethnic, linguistic, religious and national diversity (ANSD, 2009). ${ }^{6}$ The two neighbourhood representatives of Lindiane told me that increasing urbanisation brought Jola, Mandinka and other ethnic groups to Lindiane until the Bainuk, the original landowners, nearly completely disappeared, a fate they met in all of Casamance (Linares, 1992: 84-90; Quinn, 1971, 1972: 482; Roche, 1985: 28-56). Inhabitants of the neighbourhood sometimes claimed it to be dominantly Jola and sometimes Mandinka, but no one was really sure because there were also neighbours of other ethnic groups and national backgrounds. For example, the majority of corner shops are run by Fula, and Bissau Guinean refugees began settling in the north-east in the 1970s. Immigrants from more distant origins including Guinean Fula and Ghanaians, but also a German evangelical pastor and a French Catholic nun, were scattered across this part of town.

In terms of religion, Lindiane is a very mixed neighbourhood of Ziguinchor, with Muslims (mainly Qadiriyya and Tijaniyyah), Christians (mainly Catholics) and many others adhering to ethnically specific religions. A large Catholic church and a private Catholic school are located on the boulevard. A féticheur sells talismans next to the school, and a small mosque is situated a couple of blocks east of the church along the boulevard. South of it, there are two larger mosques and an evangelical church. Casamance is the region in Senegal which is the most heterogeneous in regard to religion. All departments of the Lower and Middle Casamance have a share of 7 percent to over 30 percent of Christians and shares of adherers of so-called traditional religions of up to 35 percent (ANSD, 2009). In the Kasa County west of Lindiane, Christians and traditional believers outnumber Muslims, a unique occurrence in Senegal.

Along the boulevard was the house where I stayed, Samboukunda, which reflected the neighbourhood in a nutshell. Around the same yard where I lived were some Fula shopkeepers, a Catholic teacher from Guinea Bissau with his two sisters and Jola cousin, and a Muslim Jola family from the Kalounayes with one nephew who had recently become an Ibadu. ${ }^{7}$ The various neighbours stopping by for a visit completed the picture of the diverse configuration of Lindiane.

In the two neighbourhoods, Lindiane in Senegal and Cerdanyola in Catalonia, diversity characterised the social context in which neighbourliness was an important theme from which I conclude on the process of conviviality.

\section{Convivència and Cohabitation, residency and neighbourliness}

In the following, I engage with the discourses of convivencia and cohabitation, emic concepts of living with difference. As I will show, neighbourliness is closely interwoven. As normative discourses they reference everyday practices and values on the basis of which living with difference should be possible. A similar picture emerges from both 
Casamance and Catalonia. The local discourses present a vision rather than the messiness of everyday life, which I juxtapose in detail thereafter.

\section{Catalan convivència and residency}

Casamançais in Catalonia frequently rephrased my interest in social relations in Catalonia using convivència, a local term referencing the practices of everyday living together that everyone would strive for, Catalans and immigrants alike. Casamançais crudely stated that neighbourly relations were by and large unproblematic and that some degree of conflict was normal, since there were good and bad people wherever one went. Both the political discourse and the practice of dealing with immigration in Catalonia informed this reference to convivència.

Catalan political rhetoric stressed convivència alongside interculturalism and cohesion. Un pacte per viure junts i juntes. Pacte Nacional per a la Immigració ${ }^{8}$ (Generalitat de Catalunya, 2009) and related action plans (Generalitat de Catalunya, 2005, 2010) state as their primary objective that people of different origins can live together in Catalonia. They aim to prevent conflicts of convivencia through the sharing of a common public culture, the adjustment of social services and the managing of migration flows. Within this framework, convivència gives importance to equality and plurality, alongside interaction, participation and mutual respect. The empadronament, the registration of everyone living in a locality with the council, is crucial in that it partially grants de facto equality to registered local residents - or neighbours.

The empadronament grants access to the health system and continuing education and provides proof of 'social rootedness' (Generalitat de Catalunya, 2009: 51) in a locality, one of the prerequisites for regularisation. Local politics stressed it as the most important element of starting a life in Catalonia. In combination with relatively little policing, the empadronament established a situation of de facto local residency independent of legal immigration status and origin. From a Casamançais perspective, it balances the perceived inequality between international migrants and others, providing a common identity as locals. Providing the locality as a common point of reference, the empadronament is a basis for convivència.

Actual convivència among neighbours cannot be conflict-free. The Catalan discourse on convivència has a prominent counterpart in the Andalusian history of cooperative and conflictual coexistence of Muslims, Christians and Jews in the Middle Ages in Al-Andalus. Liliana Suárez-Navaz (2004) mentions that a contemporary vernacular understanding of convivència persists in Andalusia today. According to her, convivència is 'an exercise of negotiation that assumes difference as a basic fact of life and the need to make room for dialog among all members of society, respect for one another, and sharing the public social sphere' (Suárez-Navaz, 2004: 191f). This mirrors Catalan policy, adding the important detail that convivial practices apply to dealing with both harmonious relations and conflict.

In Mataró, all immigrants were exposed to this official Catalan discourse of convivència through a public campaign advertising the Pacte Nacional and the reception service of the town for 'new citizens'. The curriculum of the free and voluntary reception classes stressed the different aspects of living a life in Catalonia starting with the importance of 
the empadronament, continuing with work, social services, and general rights and duties. Convivència reoccurred throughout all sessions through the aspect of language learning, the general orientation in town, information about lifestyles in Catalonia, neighbourly relations and others. These classes directly confronted everyone attending with the Catalan notion of convivencia which was reflected in the wide familiarity of Casamançais with it and the circulation of everyday knowledge of the neighbourhood life among them. Nevertheless, Casamançais often referred back to experiences of cohabitation and voisinage in their places of origin.

\section{Casamançais cohabitation and voisinage}

Discussing local social relations with Casamançais, in Catalonia they often used convivència and the French cohabitation (living together) and voisinage (neighbourliness) interchangeably. In their mother tongues, Casamançais most often referred to variations of bukinor (Jola) and siiñooyaa (Mandinka). Although the literal meaning of bukinor and siiñooyaa diverge, they are closely linked. Bukinor stems from the Jola verb - kinor, which means 'to live together'. It thus translates into cohabitation. The Mandinka siiñooyaa, however, contains the noun siiñoo, 'the neighbour', paralleling voisinage. This close linking by Casamançais of voisinage and cohabitation, created through their interchangeable use, manifests the centrality of neighbourliness for the living together with difference - conviviality - in their place of residence.

When explaining the duties of a neighbour, the cohabitant, my interlocutors equated them with those of a family member. This was strongly put forward in the phrase 'Ton voisin est ton plus proche parent' ${ }^{9}$ In a diverse urban setting, I was told that all people should be treated alike, whether they belonged to your household or family. In this discourse, Casamançais not only identified those in one household as cohabitants, but also all those who lived in the same neighbourhood. Neighbourliness precisely took the place of family obligations in such situations where not everyone was a family member. Speaking of neighbours, Casamançais acknowledged cultural differences and built them into their conception of sharing the same locality. While not being fully equivalent, it constituted a good foundation for relating to being a resident in Catalonia.

Using voisinage and cohabitation, Casamançais took part in a discourse describing relevant practices expected of a neighbour with whom they shared the same locality. Throughout my fieldwork, this frequently implied mutual help, support and sharing, similar to the ways expected within the family. The envisioned behaviour was one of respect, consultation, consideration and forgiving. In the discussions, a strong normative framework became apparent that prescribed what was possible or not, wanted or not, and good or bad. How this played out in practice remained slightly obscure to the point that Casamançais gave me concrete examples of interactions between neighbours. While in my fieldwork outside of Casamance I was mainly given positive examples of good neighbourly relations, during my time in Casamance, I also learned how neighbourliness implied conflicts and the solving of these conflicts.

In both sites of my fieldwork, there were notions that prescribed how to go about everyday life while dealing with difference in a shared locality. In Catalonia, convivència to a large extent was based on residency, and thus was connected with the idea of the 
equality of all residents. In Casamance, the notion of the neighbour referred to everyone who had settled in a neighbourhood, especially when there was no group that could claim precedence over the others. While neighbourliness was used literally in the latter, in Catalonia it was implicit in the idea of residency in a shared locality. Interestingly, both discourses used categories that are neutral to social and cultural difference. Thus, referring to a situation in which people of different origins live together, these emic notions of conviviality conceptually assume sociocultural differences as the underlying condition. While this is important in developing the conceptual notion of conviviality, how neighbourliness plays out in practice turned out to be complex and at times contradictory.

\section{Ethnography of neighbours}

The emic discourses and references to neighbourliness in Catalonia and Casamance stress a number of the same practices as being crucial for success. Yet, Casamançais also suggested that values and norms were at least partially adjusted and changed to fit specific situations. Some practices of Casamançais clearly continued but also changed depending on the local context. As part of their Casamançais understanding of neighbourliness, literal translation between languages was common and had an important counterpart in the translation of concepts. Negotiation practices paralleled conceptual translation and resulted in mutually agreed consensuses involving consideration and respect. If translation and negotiation failed, neighbours experienced various degrees of social breakdown. Furthermore, things became fundamentally different when neighbours assumed extreme positions and either enacted quasi-kinship solidarity or pure individualism. Exploring each of these situations in turn, I engage with the dynamics between practice-oriented and normative aspects of neighbourliness, their significance for the conceptualisation of conviviality in fragile socioculturally diverse configurations and processes of local social change.

\section{Translation and interaction}

Translation was the basis for interaction in both Casamance and Catalonia. It means both the active use of multilingual repertoires and the navigation of conceptual differences and recognition of their legitimacy, which demands flexibility, generosity, openness and negotiations.

In Lindiane, most of my informants and large shares of the population had diverse linguistic skills and were therefore familiar with multiple languages. Augustin Sambou was born Jola in Guinea Bissau and, in addition to his mother tongue, spoke several languages well. At the street corner with people of his age, he often used Wolof, following a general trend among the younger generations. With his cousins from Guinea Bissau he spoke Creole, with his family members his home dialect of Jola, and with his landlord the widely spread Jola Fogny. He also knew Mandinka and some Fula. With his colleagues he spoke French, while with me he sometimes practised English; he also knew Portuguese. Augustin enacted the ideal of many of the inhabitants of Lindiane. Sometimes, this was set in contrast to the attitude of the Mandinka and Wolof, who primarily only 
speak their own language. This prejudice, however, did not always hold true. For instance, Madou Diaby, although he mainly spoke Mandinka, constantly made an effort to greet his Jola neighbours in Jola on our walks. He said he consciously did this to have good neighbourly relations. Thus, most people in Casamance saw multilingualism as a way of fostering good neighbourliness. This did not imply very high levels of proficiency for everyone. However, some level of proficiency in several languages allowing everyday communication was widely shared. My own efforts to learn the mother tongues of various groups were greatly acknowledged and sometimes interpreted as my intention to stay.

The efforts of drawing on many languages were generously acknowledged in several ways, and limitations of someone's expressions were frequently glossed over. In translation, terms that were similar enough instead of a one-to-one translation were often accepted. Siiñooyaa and bukinor have different literal meanings, but many of my informants agreed that they were conceptually close enough to mean neighbourliness. This generosity was often paired with an openness to incorporate foreign words into their phrases. For example, in discussions with Casamançais in Catalonia, convivència was often used in French conversations. This was everyday practice in Casamance: Wolof, French and Mandinka words were incorporated into other languages. Abaraka, the Mandinka 'thank you', was widely used by all ethnicities in Casamance. In these examples, a pragmatic use of languages becomes apparent which complements the analysis of Mandingisation and Wolofisation, the increasing cultural dominance of Mandinka and Wolof, respectively, over other local languages and cultures (cf. Juillard, 1994; Linares, 1992; Thomson, 2011). The acknowledgment of efforts and differences is paired with a positive and joyful engagement with translation. Originating from an initial attempt to communicate with neighbours, translation legitimises differences between people and their languages as a part of everyday conviviality. This central aspect of a Casamançais conception of neighbourliness migrated with them to the Catalan context.

Casamançais in Catalonia occasionally interacted with their Spanish and Catalan neighbours. For this reason, many Casamançais in Catalonia spoke enough Catalan to engage in the fleeting forms of casual greeting: 'Hola! Bon dia! Com estàs? Tot be'. ${ }^{10}$ Keba Deme, a Jola, suggested that such little steps were already enough to create a cooperative neighbourly atmosphere. Going beyond such minimal knowledge, Abib Drame, a young Mandinka, explained that he had gone to learn the language, because for him communication, which was facilitated by language learning, was crucial to neighbourliness and to being able to interact with people. ${ }^{11}$

While the above claims to greeting were part of an attempt to literally transfer a strong value from Casamance into the Catalan context, Casamançais frequently stated that they were not understood by other local residents. Translation goes beyond the literal sense, requiring the reinterpretation of concepts and adjusting oneself to the new local context. Fanta Diao, a Fula woman from Casamance, experienced this in the house she had moved into with her husband and baby. While her default was to greet the other residents she encountered in the house, she stopped greeting those who did not respond. However, Fanta felt that the White woman in the house who did greet her - whether she was Catalan, Spanish or Latin American, Fanta could not tell - practised good neighbourly 
relations. Greeting selectively or not at all was often perceived to be the norm in Catalonia, to which Casamançais felt the need to adjust.

Greeting was just one example of other neighbourly interactions of which Fode Sadio Faty gave more details:

These relations [between block inhabitants] you cannot force. Maybe I can force it with my compatriot; I can come to see him without notifying him, ... like in Africa. But the one who is next to me, the European, I cannot do it the way I did it there. I observed. I noticed that there is a bit of reticence, a bit of individualism here. ... Because, first of all, no one opened the door for me. ... I adopted that. If we meet in the staircase, we greet, 'Salut' - 'Salut', 'Hola' - 'Hola' - 'Hola'. This is all. Sometimes there is not even a 'Hola'. (Fode Sadio Faty, Granollers, $11 / 2010)$

No spontaneous visits, individualism, reticence, superficial relations, minimal greeting and keeping problems to themselves are the essence of Fode Sadio's observation of his neighbours. He does not judge these differences; instead, he described the process of translation that he engaged in when he arrived.

Translation is key in the interaction of neighbours both in Casamance and Catalonia. Understood as linguistic capacity, it facilitates interaction. In combination with nonverbal communication, Casamançais translated concepts and practices; they made an effort to understand differences. This is often motivated by the quest for consensus which requires negotiation.

\section{Successfully negotiating neighbourliness}

Most of the time, Casamançais refrained from open conflict, and examples of successful negotiations of neighbourliness were plenty during my fieldwork. One central element is the negotiation of practices in spaces shared with neighbours.

On a hot afternoon in Sédhiou, I sat in the yard of Abib Samatés family and talked with Abib's wife Sally Djitte. After hours of trying to ignore the never-ending, monotonous recitals stemming from the neighbouring yard, I voiced that I was tired of it. How long were these monotonous recitals to last, I enquired. Sally smiled at me and explained that these were prayers of a Mouride dahira which would last for days and were part of the preparations for the Grand Magal to Touba (an annual religious festival held in Touba). Upon my asking whether this was going to upset anyone, Sally answered that I should know by now that in Senegal, everyone was allowed to practise their religion. Nobody would critique it or get publicly upset about it. By the time I left Casamance, I had learned that the inhabitants would certainly sometimes get tired of it, or complain and be critical of it among their closest circle. However, the standard consensus that can be reached in processes of negotiation in such situations is to let everyone do whatever their religion asked them to, whether or not it infringes on somebody else's liberties. ${ }^{12}$ Endorsing this notion and discourse, Casamançais actively encouraged different ways of life and permitted spaces for it.

In Catalonia, the Casamançais were also considerate of their neighbours; however, the dynamic that accompanied this attitude had changed. Instead of a flexible framework in which everyone tentatively and temporarily entered the spaces of others through flexible 
boundaries, the Casamançais in Catalonia restricted their own actions. A common trope was 'We are in Spain, thus we cannot ... [do certain things]'. Casamançais agreed to abstain from listening to loud music, from having big gatherings at home, from celebrating a wedding on the street or from killing their own sheep for religious feasts at home. While in Casamance, social spaces overlapped and boundaries were vague, in Catalonia Casamançais were concerned to respect not just the boundary, but rather to help build voids as buffer zones between themselves and their neighbours. To show their consideration in this way was the result of translation. Most of my informants did not see this behaviour as the result of imposed foreign norms, but rather as the normal respect for the local practice of convivència.

The retreat of Casamançais into the private realm accompanied by more limited notions of neighbourliness was in stark contrast to experiences of celebrations on neighbourhood streets in Casamance in which some neighbours assisted and all of them consented. In celebrating a wedding, a baptism or a funeral in the neighbourhood street, neighbours claimed the communal space and thereby limited access to houses or the circulation of traffic. Furthermore, noise emissions from celebrations transcended all walls, closed doors and other physical boundaries. As at major religious events, everyone was invited to partake in the celebrations, and a lot of people actually did participate. Exceptions were those who were physically present and even financially supported events, such as some returning migrants, but who never drank or ate at their neighbour's house out of fear of being poisoned. They hereby substantiated their claim that the relations between neighbours could be tense and subject to envy and cursing. To maintain face and sustain neighbourliness, alternative explanations for not eating were found and given as excuses.

Despite such inconsistencies which eventually could also lead to local change, the celebrations in public space in Casamance embodied the consensus that had been negotiated between the neighbours. It granted everyone the right to claim communal spaces to celebrate their festivities in exchange for inviting everybody to participate. In Catalonia, however, public gatherings were not necessarily a site of extended interaction, although they did happen and were part of Catalan convivència (Heil, forthcoming). More than in Casamance, in Catalonia interactions in public were minimal, since some everyday interactions from Casamance were classified as annoyances rather than good neighbourliness. Thus, Catalan neighbourliness was dominated by abstaining from certain practices that could impinge on each other's privacy, while in Casamance it implied respecting the activities of neighbours actively being engaged in them. It shows that in both cases, locals negotiate the rules of neighbourly interactions. If consensus becomes impossible to reach, conflicts can lead to social breakdowns.

\section{Accusations and social breakdowns}

Neighbourliness both in Casamance and Catalonia could be challenged through mutual accusations of not adhering to social norms. Such cases of failing everyday negotiation and translation demanded institutional mediation. In this contribution, I focus on two outstanding examples. First, in contrast to efforts to successfully practise neighbourliness, the issue of roaming animals was often an arena for mutual contestation and 
conflict in Casamance. Second, Casamançais in Catalonia recalled accusations in their apartment buildings and instances of xenophobia, which they interpreted as forms of missing respect and the absence of neighbourliness.

Animal husbandry was a common phenomenon in Casamançais towns as were gardens for the cultivation of vegetables. Roaming animals were most commonly cited as the prime source of conflict in neighbourhoods. A neighbourhood delegate in Ziguinchor, Yoro Taffa Sambou explained that it was generally forbidden to let animals roam free, but that the consensus was that during the dry season they may do so. Exemplifying his point, Yoro recounted that he recently had been asked to settle a conflict between a lady and her neighbour. Without the necessary proof, the lady accused her neighbour's pigs of destroying her garden. Soon afterwards, the neighbour reported the lady having poisoned his pigs. Yoro sent them to the police, since neither of the two accusations was verifiable and his mediation failed. While such cases were often termed as a religious conflict, Yoro juxtaposed that it was not just pigs, but also goats and sheep causing the same conflicts. Yet, he could not deny that while a sheep or goat was of direct use to both Christians and Muslims, a pig was not. In the former case, a common solution was for plaintiffs to keep those animals penned in their garden. In the latter, a settlement was more difficult since it involved taking the pigs into custody until the plaintiff's damage was paid. Only if such negotiation failed did the police step in as a higher ranking institutional mediator.

Many of my informants recalled such incidences of ungrounded accusations and conflictual neighbourly relations. While in Casamance different ways of living were readily accepted, when the livelihood of one person was put at risk, conflicts arose. Neighbourly relations thus need to be negotiated in a way that everyone's livelihood is secured. By the same token, Casamançais in Catalonia accepted the restrictions on public celebrations and at home under one condition: everybody needed to get up early in Europe to work, and thus everyone needed more space and time to recover. Other challenges in neighbourly relations based on prejudices and open discrimination, however, remained unacceptable.

In Catalonia, Ansou Diédhiou felt disrespected and accused for no reason when his Moroccan neighbour blamed his wife a number of times for having dropped dirty nappies on clean washing. The Moroccans accused her without proof. And even worse, so did the president of the apartment block when he accompanied the Moroccan husband to blame Ansou's wife in Ansou's absence, the second time round. Ansou felt there was a huge discrepancy in dealing with the situation. He neither felt respected nor regarded as equal since his family was the only one suspected. Furthermore, the president had sided with one party and in the eyes of Ansou had broken the local consensus which ascribed the president the role of a neutral mediator. In the end, Ansou's inquiry identified the real origin of the nappies as the top floor of the house, where a Spanish woman was visiting every so often with her new-born and the nappies had fallen from that floor by accident. Feeling that both his neighbour and the president of the block had broken the rules of neighbourliness, Ansou temporarily found peace in filing a complaint with the local police in case such unfounded accusations would reoccur. As a consequence, Ansou's distrust in working neighbourliness in Catalonia had increased.

Similarly, other informants in Catalonia recalled how they were first met with racism, negative stereotypes and missing respect. Many of them, however, managed to settle 
their problems through communal mechanisms in place, acquainting themselves with the locals, or at least local norms. Testing neighbourly relations was part of this process. A striking example is that of Sounkar Deme, who had just moved into a new apartment block and met a neighbour who readily offered to help out whenever she could. Not needing anything, Sounkar tested her twice, once asking for oil and once for onions, which she offered to him immediately. More frequently, Casamançais took part in the apartment block meetings, appreciating the role of their president who for many facilitated the process of communicating and negotiating common norms. Going to the police, as Ansou did, remained an exception during my fieldwork. According to the Casamançais' experience, the absence of interaction and negotiation and the non-engagement with the neighbours can be seen as the basic source of missing respect, accusations and xenophobia, and thus as a real challenge to conviviality.

Rather than no interaction, conflictual ones were also part of neighbourhood life in Casamance and thus form part of my conception of conviviality. The centrality of tensions reflected the Casamançais' apprehension of the fact that 'there are good people and there are bad people, everywhere'. Lived neighbourliness depended on both local and transnational influences that played out differently depending on the actual situations and the people involved. Thus, neighbourliness cannot be unambiguously evaluated in either of the two field sites, nor can a fault line be drawn according to ethnicity or nationality, that is, Casamançais versus non-Casamançais, or immigrant versus European. Rather, neighbourliness is something enacted according to norms that in the eyes of my informants apply to people who are co-resident in the neighbourhood. Furthermore, these norms change and are negotiated in the migration process. The Casamançais' example shows that this negotiation is an ongoing process. Conflictual encounters as well as cooperative ones are part and parcel of it.

\section{Solidarity and individualism}

In both Casamance and Catalonia, neighbourliness varied on a scale between the mechanical solidarity of kinship groups and the pure individualism often attributed to a European way of life. As one among many, Papis Sonko in Ziguinchor was very outspoken about how neighbours become the closest relatives to one another. As I mentioned in the introduction, he perceived the absence of biological kin as the cause for the necessity of good neighbourliness. This crossed religious, cultural and class differences. As Seyni Badji in Lindiane told me, 'S'il y a du bon ou du mal, c'est le cohabitant qui s'en

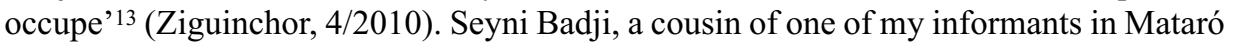
and the interim head of a primary school, hereby explained the symbiosis between his family and that of his widowed neighbour Évelyne Diadhiou. At the Christian communion of Évelyne's daughter, the neighbours, most of whom were Muslim, took on the organisation of the event to relieve Évelyne. Such help is a common phenomenon of neighbourliness. It relies on both the agreement that all of them profit from their mutual help and the fact that they play down differences between Muslims and Christians translating the various ritual practices for each other.

On the day of Tabaski (Id al-Adha), the preparations for slaughtering the animals in Damé Sambou's house was also an instance of neighbourly help. In the absence of a 
sufficient number of Muslim adult men living in the Jola Samboukunda house, the Muslim Mandinka neighbours prepared and washed the sheep to be slaughtered, portraying their help as normal and as their duty. Equally, the head of the Mandinka household, a woman, told me how Damé Sambou, after having moved to the neighbourhood and before returning to Spain, had entrusted her with keeping an eye on the family. Although she did not agree with all of the measures Damé was taking for his family, she continued to maintain good relationships, regularly inquiring about the family and trying to be diplomatic. Upholding her attitude as a good neighbour was in contrast to the gossip among all other neighbours about Samboukunda and especially about the upbringing of Damé's children, as the woman disclosed to me in private.

One last example shows that neighbourliness is alive despite socio-economic differences among residents. In the adjacent block to Samboukunda was Sagnakunda, the house of the head of the polytechnic school of Ziguinchor. The oldest daughter in charge of the household chores often engaged in friendly, civil interaction with neighbours such as those sitting outside next door. Their interactions consisted of both shorter and more extended forms of greeting and inquiring about the wellbeing of the families. This is significant in a neighbourhood where richer people live in relative proximity to poor ones. More ostentatious than Sagnakunda was the large, two-storey house of the family of an Air France employee. There were also a number of better-off households of migrants, such as Damé Sambou's, in the neighbourhood as well as of rich Fula traders. On the other hand, there were relatively poor households surviving on virtually nothing, for example those of some Guinean refugees. While people living in the locality perceived such differences in socio-economic status, neighbourliness was nevertheless enacted, at least in the form of exchanging multilingual greetings.

Thus, in Casamance, everyday neighbourliness of various intensities and levels of obligation crossed all forms of differentiation: religion, ethnicity and class. It is this very general notion of neighbours that does not have any other prerequisite than the legitimate sharing of a locality that was the basis of cohabitation and convivència. Kinship-like solidarity among neighbours is the strongest sign of it, greetings and assertions of good neighbourly relations are weaker ones. This is in stark contrast to individualism, a stereotypical European value that comes to influence the local sociality in quite a different way.

Instead of seeking individual success and maintaining a favourable public position embedded in the local social field (Timera, 2001), Casamançais respondents risked discrediting the solidarity aspect of neighbourliness by pre-empting 'European' individualism and disrespecting local social values. This could happen both once they arrived in a quintessentially European space such as Catalonia and when they aspired to a modern life in Casamance. In the latter case, they were torn between admiring and critiquing visiting migrants from Europe (Riccio, 2005). Concerning Catalonia, the guiding statement was clear: 'Chacun pour soi, et dieu pour tous', ${ }^{14}$ the latter part frequently being omitted. This focus of everyone on their individual lives, both concerning success and difficulties, in Catalonia explained crucial aspects of two parallel and intertwined processes: first, the changing conceptualisation of neighbourliness of Casamançais in Catalonia, and second, as I have discussed above, the partial discrepancy between expectations and experiences of neighbourly relations in Europe. 
In Catalonia, Alain Sagna reflected how, on the one hand, neighbourly help had become absent in everyday experiences, and how, on the other hand, he himself tried to engage in an individualistic lifestyle. He explained that at home, someone in the neighbourhood would provide rice anonymously to a crisis-struck neighbour. In Europe, however, one would need to actively ask, which he was convinced was unwise. If he went to ask his Casamançais friend in the neighbourhood for rice on a Sunday, the next day every Casamançais in the Cerdanyola neighbourhood would know about it and await his economic demise. Such a loss of social status, indirectly admitting the failure of the migration project, was not what he desired. In his eyes, neighbourliness had deteriorated from positive help into Schadenfreude. This was a rather negative portrayal compared to migrant solidarity that was also experienced (cf. Heil, 2013; St Jacques, 2009), and it exemplified the fine balance that Casamançais sought between individual success and group solidarity (Riccio, 2005: 116). Alain and others reacted to this by avoiding social interactions, leaving their apartments only when necessary, and exposing themselves as little as possible to neighbours. For them, neighbourliness in Catalonia was something negative or non-existent.

In urban settings in Casamance, some of the younger generation had also retreated from stronger forms of neighbourliness and even advised me not to greet people in the street, since they found it unsuitable. Others also complained continuously about the burden the different forms of solidarity placed on them, both within the family and the neighbourhood. They envied their brothers and friends whose migration had freed them from it. They thus tried to avoid social obligations and ascribed to an individualistic lifestyle that they perceived as modern. Ultimately, they intended to quit the social networks in which they had been unable to gain social standing (cf. Timera, 2001: 47). This constituted a similar development to the changes Casamançais perceived in Catalonia. However, in Casamance it was actively pursued by Casamançais in rejection of a former local habitus, while in Catalonia it was experienced as acquiring an existing local habitus. In both cases, Casamançais turned their backs on the neighbourly practice of maintaining interactions. Even if such a quest for autonomy does not fully prevent conviviality, it changes its form and content.

\section{Conclusion}

In this contribution, I have explored modes of living together with difference through the lens of neighbourliness. The brief exploration of the discourses of convivència in Catalonia and cohabitation and voisinage in Casamance has shown that the idea of neighbourliness is central to the discussion of conviviality, living with difference in a shared locality. The emic discourses appear similar in both sites of my comparison and suggest a common set of practices and values. They stress interaction and participation involving translation and negotiation on the basis of equality and respect. My ethnography has shown, however, that while the discursive frameworks in the two places are similar, the actual habitus of neighbourly interactions varies from site to site. Casamançais reflected upon this in their representations of neighbourliness in Catalonia. Analytically, I therefore chose a comparison of interaction, negotiation and translation, which I suggest are some of the crucial basic practices of everyday conviviality. Everywhere, they 
comprise both cooperative and conflictual aspects of everyday life, and ways of dealing with them peacefully. Based on this ethnography of various cooperative and conflictual interactions of neighbours, I will now conclude by answering the questions raised in the introduction of how discourses related to neighbourliness influence everyday practices and the conceptualisation of conviviality, and how transnational continuities in living with difference contrast with distinctively local influences.

Closely related to the notion of neighbourliness, the local discourses of convivència and cohabitation reveal both practices and values important for living together with difference. Additionally, I have argued that providing the categories of 'neighbour' or 'resident' in Casamance and Catalonia, respectively, is of particular importance, since they span sociocultural, socio-economic and even legal differentiations. In the absence of other more meaningful reference systems for social interaction in urban settings and in view of the limits of networks on the basis of kinship or shared origin, providing notions with local reference such as neighbour or resident is of major importance. It establishes a potential basis for sufficient equality and respect that is crucial for a successful process of conviviality.

While I have observed that the practices of negotiation, translation and interaction are locally relevant in both sites, distinct influences loom large in my analysis concerning how these ideals are put into practice. Casamançais in Catalonia experienced an inherent contradiction: well aware of how to deal with differences in Casamance, Casamançais partly imagined and partly experienced sharing a convivial habitus, a set of norms and practices that successfully and continuously negotiated differences. In Catalonia, they experienced that this habitus was no longer shared among all residents of a neighbourhood, which resulted in a need for renegotiating norms and practices and a repositioning in this specific local social field. Prominent forces in this process were the representation of European individualism and of African solidarity that exerted different levels of power across the transnational social field. Thus, while some aspects of neighbourliness persist throughout the migration process, such as the vivid engagement with translation, local dynamics lead to the renegotiation of others, which results in social change due to migration. This changes the relations of all residents in both localities, and not just the habitus of the Casamançais migrants.

Change, however, is not restricted to the influences of migration, and the ethnography has also revealed general change over time. Cohabitation in Casamance was not static but was permanently re-enacted, negotiated and subject to change. A modern life inspired by European individualism challenged neighbourliness, and Casamançais multilingualism faced the growing popularity of Wolof among the younger generations. Finally, convivencia in Catalonia was subject to wider developments that had little to do with the neighbourhood scale and migration. The current economic crisis and political responses will not pass unnoticed and potentially challenge the current political practices of residency and semi-regularity that have so far been an important foundation for convivial practices.

I have thus shown that neighbourliness is a valid field of study for conceptualising conviviality, the fragile process of living together with difference. Suggested by an initial focus on neighbourliness, the basic practices of interaction, negotiation and translation are central for a concept of conviviality and appear in both cooperative and conflictual 
situations. This has proven to be productive for an analysis of indeed fragile, changing and socioculturally diverse configurations.

\section{Acknowledgements}

I would like to thank all the people who participated in this research project and who had me participate in their everyday activities both in Senegal and Spain. Furthermore, I would like to thank all the participants of the conference 'Comparing Convivialities. Dreams and Realities of Livingwith-Difference' in Göttingen, Germany, for their constructive feedback and Margaret Loney, Marisa Macari, Fran Meissner, Magdalena Nowicka and three anonymous reviewers for their detailed comments on earlier drafts of this paper.

\section{Funding}

This research was conducted with the support of a Doctoral Fellowship of the German Academic Exchange Service, a language grant by the Institute of Social and Cultural Anthropology, University of Oxford, UK and a Doctoral Research Fellowship at the Max Planck Institute for the Study of Ethnic and Religious Diversity, Göttingen, Germany.

\section{Notes}

1. 'Your neighbour is your closest relative' (from French).

2. All names have been changed. However, the first name shows the Christian or Muslim faith of an informant, while the last name indicates the ethnic origins of the person. Where the latter is crucial for the analysis, the ethnicity is additionally mentioned separately.

3. Between 2007 and 2010, I conducted long-term fieldwork in Lower and Middle Casamance, mainly in the regional capitals of Ziguinchor and Sédhiou, and in Catalonia, mainly in Mataró. I primarily undertook participant observation, which resulted in daily field notes, and I conducted a total of 66 semi-structured, open-ended, recorded interviews. Most of the fieldwork was constructed around people linked to 10 households in Mataró and 6 households elsewhere in Catalonia (cf. Heil, 2013).

4. Studies mostly subsume the Casamançais under the Senegambian category (Kaplan Marcusán, 1998, 2003, 2007; Sow, 2004, 2005). I suggest (Heil, 2012) that many of the more than 18,500 of the more than 60,000 Senegalese in Catalonia are Casamançais (Instituto Nacional de Estadística, 2011).

5. I take the share of the Moroccan population as the best albeit a conservative proxy for Muslims.

6. Compare with Leary $(1970,1971)$ for conversion movements of Muslim marabouts; Bâ (1986), N'Gaide (1999) and Quinn (1971) for the Fula independence struggle causing migrations; Foucher (2002: 64), Mark (1976, 1977) and David (1980) for seasonal migration; and Hamer (1981), Linares (2003), Lambert (2002), Foucher (2002) and Reboussin (1995) for urban migration to Banjul and Dakar.

7. The Jamaatou Ibadou Rahmane movement is a Senegalese reformist movement that seeks to install orthodox Islam and that derives its name from the Qur'anic term Ibadu ar-Rahman, 'Slaves of the Merciful' (Loimeier, 2000; Villalón, 2004).

8. 'An Agreement to Live together. National Agreement on Immigration' (from Catalan).

9. See Note 1 .

10. 'Hello! Good day! How are you? Fine' (from Catalan).

11. For a more detailed discussion of the relationship and competition between Catalan and Castilian, as well as Catalonia and Spain, see my own discussion elsewhere (Heil, 2012). 
12. The celebrations of Tabaski and the Easter celebration in Lindiane exemplified this attitude on a larger scale (Heil, 2014).

13. 'Whether something good or something bad happens, it is always the cohabitant who takes on what needs to be done'.

14. 'Every man for himself, and God for us all' (from French).

\section{References}

Ajuntament de Mataró (2010) Estudi de la Població. Mataró: Servei d’Estudis i Planificació.

ANSD (2009) Recensement général de la population et de l'habitat 2002 (personal communication). Ziguinchor: Service Régional de la Statistique et de la Démographie.

Bâ C (1986) Les Peul du Sénégal: Étude géographique. Dakar, Senegal: Nouvelles Editions Africaines.

Bover O and Velilla P (2005) Migrations in Spain: Historical background and current trends. In: Zimmermann KF (ed.) European Migration: What Do We Know? Oxford: Oxford University Press, pp.389-414.

David P (1980) Les navétanes: Histoire des migrants saisonniers de l'arachide en Sénégambie des origines à nos jours. Dakar, Senegal: Nouvelles Editions Africaines.

Foucher V (2002) Cheated Pilgrims: Education, Migration and the Birth of Casamançais Nationalism (Senegal). London: School of Oriental and African Studies, University of London.

Generalitat de Catalunya (2005) Pla de ciutadania i immigració 2005-2008. Barcelona: Generalitat de Catalunya.

Generalitat de Catalunya (2009) Un pacte per viure junts i juntes. Pacte nacional per a la immigració. Barcelona: Generalitat de Catalunya.

Generalitat de Catalunya (2010) Pla de ciutadania i immigració 2009-2012. Barcelona: Generalitat de Catalunya.

Hamer A (1981) Diola women and migration: A case study. In: Colvin LG, Ba C, Barry B, et al. (eds) The Uprooted of the Western Sahel: Migrants' Quest for Cash in the Senegambia. New York: Praeger, pp.183-203.

Heil T (2012) Fragile convivialities: Everyday living together in two stateless but diverse regions, Catalonia and Casamance. COMPAS Working Papers, WP-12-100.

Heil T (2014) Dealing with diversity and difference in public. Traces of Casamançais cohabitation in Catalonia? In: Grodz S and Smith GG (eds) Religion, Ethnicity and Transnational Migration between West Africa and Europe. Leiden: Brill.

Heil T (2013) Cohabitation and Convivencia. Comparing conviviality in the Casamance and Catalonia. Unpublished DPhil Thesis, Institute of Social and Cultural Anthropology, University of Oxford.

Instituto Nacional de Estadística (2011) Revisión del padrón municipal 2010. Datos a nivel nacional, comunidad autónoma y provincia. Madrid: INEbase.

Juillard C (1994) Demain, Ziguinchor, ville plurielle? Indices de la wolofisation en cours. In: Barbier-Wiesser FG (ed.) Comprendre la Casamance: Chronique d'une intégration contrastée. Paris: Karthala, pp.401-412.

Kaplan Marcusán A (1998) De Senegambia a Cataluña: Procesos de aculturación e integración social. Barcelona: Fundación 'la Caixa'.

Kaplan Marcusán A (2003) Los procesos migratorios: Senegambianos en Cataluña. Barcelona: Departamento Antropología Social y Cultural, Universidad Autónoma de Barcelona.

Kaplan Marcusán A (2007) Las migraciones senegambianas en España: Una mirada desde la perspective de género. In: Iniesta F (ed.) África en Diáspora. Movimientos de población y politicas estatales. Barcelona: Fundació CIDOB, pp.153-167. 
Lambert M (2002) Longing for Exile: Migration and the Making of a Translocal Community in Senegal, West Africa. Portmouth: Heinemann.

Leary FA (1970) Islam, politics and colonialism: A political history of Islam in the Casamance region of Senegal (1850-1914). PhD Dissertation, Northwestern University.

Leary FA (1971) The role of the Mandinka in the Islamization of the Casamance, 1850-1901. In: Hodge CT (ed.) Papers on the Manding. Bloomington, IN: Indiana University, pp.227-248.

Levitt P and Glick Schiller N (2004) Conceptualizing simultaneity: A transnational social field perspective on society. International Migration Review 38: 1002-1039.

Linares OF (1992) Power, Prayer and Production: The Jola of Casamance, Senegal. Cambridge: Cambridge University Press.

Linares OF (2003) Going to the city ... and coming back? Turnaround migration among the Jola of Senegal. Africa 73: 113-132.

Lligadas J (2000) Cerdanyola, el barri gran de Mataró 1920-2000: Construir la vida des de la immigració dels anys 50. Mataró: Patronat Municipal de Cultura.

Loimeier R (2000) L'Islam ne se vend plus: The Islamic Reform Movement and the state in Senegal. Journal of Religion in Africa 30: 168-190.

Mark P (1976) Economic and Religious Change among the Diola of Boulouf (Casamance), 19801940; Trade, Cash Croping and Islam in Southwestern Senegal. New Haven: Faculty of the Graduate School, Yale University.

Mark P (1977) The rubber and palm produce trades and the Islamization of the Diola of Boulouf (Casamance) 1890-1920. Bulletin de l'IFAN, série B 39: 341-361.

Moreras J (2008) Musulmans a Catalunya. Radiografia d'un Islam implantat. Barcelona: Institut Europeu de la Mediterrània.

N'Gaide A (1999) Conquête de la liberté, mutations politiques, sociales et religieuses en haute Casamance: Les anciens Maccube du Fuladu (région de Kolda, Sénégal). In: Botte R, Boutrais J and Schmitz J (eds) Figures peules. Paris: Karthala, pp.141-164.

Quinn CA (1971) A nineteenth century Fulbe state. The Journal of African History 12: 427-440.

Quinn CA (1972) Mandingo Kingdoms of the Senegambia. Traditonalism, Islam, and European Expansion. London: Longman.

Reboussin D (1995) From Affiniam-Boutem to Dakar: Migration from the Casamance, Life in the Urban Environment of Dakar, and the Resulting Evolutionary Changes in Local Diola Organizations. Gainesville, FL: University of Florida.

Riccio B (2005) Talkin' about migration. Some ethnographic notes on the ambivalent representation of migrants in contemporary Senegal. Stichproben: Wiener Zeitschrift für kritische Afrikastudien 5: 99-118.

Roche C (1985) Histoire de la Casamance: Conquête et résistance, 1850-1920. Paris: Karthala.

Silvestre Rodríguez J (2002) Las emigraciones interiores en España durante los siglos XIX y XX: Una revisión bibliográfica. Ager 2: 227-248.

Sow P (2004) Sénégalais et Gambien en Catalogne (Espagne). Analyse géo-sociologique de leurs réseaux spatiaux et sociaux. Geographía Humana. Barcelona: Universitat Autònoma de Barcelona.

Sow P (2005) Migrations sénégalaises en Catalogne: Diagnostic, formes de relations/communications et solidaires avec les lieux d'origin. Barcelona: Fons Català de Cooperació al Desenvolupament.

St Jacques E (2009) Economic mobility and the transnational practices of West Africans in Catalonia, Spain. Graduate School. PhD Dissertation, University of Florida.

Suárez-Navaz L (2004) Rebordering the Mediterranean: Boundaries and Citizenship in Southern Europe. Oxford: Berghahn Books. 
Thomson S (2011) Revisiting 'Mandingization' in coastal Gambia and Casamance (Senegal): Four approaches to ethnic change. African Studies Review 54: 95-121.

Timera M (2001) Les migrations des jeunes Sahéliens: Affirmation de soi et émancipation. Autrepart 18: 37-49.

Villalón LA (2004) Islamism in West Africa: Sénégal. African Studies Association 47: 61-72.

\section{Biographical note}

Tilmann Heil is a Postdoctoral Researcher at the Centre of Excellence 'Cultural Foundations of Integration' at the University of Konstanz. Prior to this, he was a Doctoral Research Fellow at the Max Planck Institute for the Study of Religious and Ethnic Diversity, Goettingen. As part of his doctoral research at the University of Oxford, he focused on discourses, practices and transnational experiences of diversity, conviviality and migration in Catalonia (Spain) and Casamance (Senegal). Previously, Heil studied geography, history and political science at the Humboldt University of Berlin, and completed an interdisciplinary MPhil in Migration Studies at the Centre on Migration, Policy and Society (COMPAS) at Oxford in 2008. 